\title{
Students' creative thinking skill in solving higher order thinking skills (HOTS) problems
}

\author{
M. Zaiyar ${ }^{1}$, Irfan Rusmar ${ }^{2}$ \\ ${ }^{1}$ Program Studi Pendidikan Matematika Fakultas Tarbiyah dan Ilmu Keguruan, IAIN Langsa \\ ${ }^{2}$ Program Studi Agribisnis Kelapa Sawit Politeknik Teknologi Kimia Industri Medan \\ $\llbracket$ relevantm.zaiyar@iainlangsa.ac.id
}

\section{Article Information \\ Submitted April 03, 2019 \\ Revised June 15, 2020 \\ Accepted June 15, 2020}

\section{Keywords}

Creative Thinking Skill; HigherOrder Thinking Skill Questions.

\section{INTRODUCTION}

\section{Abstract}

Creative thinking skills one of the important aspects that must be possessed by students' mathematical thinking skills to connect mathematical concepts as well as the development of thinking processes in solving mathematical problems. The purposes of this research are to determine the level of students' creative thinking skills in solving Higher-Order Thinking questions and to investigate the students' creative thinking skills in solving Higher Order Thinking Questions. This research employed the descriptive qualitative method with 28 students who have passed the Calculus subjects the samples of the research determined through nonprobability sampling. The data were collected through tests and interviews. The research discovered that the average score obtained was $38.43 \%$, specifically $35.71 \%$ of the students were at the very creative level, $50 \%$ of the students were at the creative level, and $14,29 \%$ of the students were at the fairly creative level. Students' creative thinking skills were lacking in creativeness and detail indicators. They were not able to solve problems properly and correctly. The fluency and flexibility indicators were in a good category. So, it can be concluded that the level of students' creativethinking skills in solving the Higher-Order Thinking Skills problems was at the creative level.

The development of science and technology has changed much of the mathematics education world. Not only in the aspect of learning mathematics but also in the attitudes towards mathematics learning. Therefore, apart from mathematical content, the process thinking and attitude are also core components that must be carried out in mathematics learning at every level of education. The application of a scientific approach in the 2013 curriculum is expected to be able to create more active, collaborative, and participatory mathematics learning and be able to stimulate students to think critically, creatively, and analytically, even able to foster creativity.

Nowadays, mathematics teaching places more emphasis on enabling students to think at a higher level (HOTS) because HOTS can be considered a fundamental skill in thinking and using mathematical knowledge in completing tasks such as reasoning skills, problem-solving skills, communication skills, questioning skills, and skills conceptual. These skills are very important in learning mathematics. Learning mathematics has many problems stemming from their weaknesses in this skill. The output of learning is expected that students will be able to develop and use their skills to build their mathematical knowledge as lifelong learning.

Thinking is the skill to understand something to overcome the problems faced in the form of new knowledge. In solving problems, someone unconsciously uses various types of thinking or even combines these types of thinking to produce a decision or solution in solving problems.

How to cite

E-ISSN

Published by 
In the application to learning in college, thinking skills enable the students to see various perspectives to solve problems in certain situations. Thinking skills possessed by students will facilitate them to complete their tasks.

The results of a survey conducted by PISA in 2018 stated that Indonesian mathematics students were still classified as low. The reading, math, and science scores were respectively 371, 379, and 396. These scores had decreased compared to the survey conducted in 2015 (Schleicher, 2018), Based on the TIMSS survey results in 2016, Indonesia obtained a score of 397 in the field of Mathematics. It also placed Indonesia 45th rank out of 50 countries while in the field of Science, Indonesia obtained a score of 3 (TIMSS, 2015). The survey illustrates that Indonesian students were categorized as low in the mastery of the material and were facing difficulty in answering questions that required reasoning. Students are poorly trained in completing HOTS problems and the lack of skill assessment instruments designed specifically for HOTS (Kusuma et al., 2017). The results also show that the mathematical literacy skill of Indonesian students based on international studies was unsatisfactory so that when they continued their study to the university level, they faced obstacles in learning since the university level required them to be more independent in learning.

In general, the higher-order thinking skills are only seen in the senior high school students, not university students. It is similar to the research results by (Siregar, 2012) that states that creative thinking skills are still low in the aspects of fluency, flexibility, and novelty. (Fitriarosah, 2016) also states that in the aspect of fluency, the students have not been able to provide many solutions to the problems given because the students' answers are only fixated on the teacher's explanation, so they have not been able to think creatively. However, in the higher education level, the higher-order thinking skills were in a low category. Based on the results of interviews and initial tests of higher-order thinking skill on 30 students of IAIN Langsa, 12 students were unable to give concrete reasons for the questions given in the calculus course, even 5 of them could not write the answers correctly.

The lack of skills to solve higher-order thinking skills problems in the calculus course was caused by the learning process that was not focused on developing higher-order thinking skills. The learning has been focused on one direction where the student less aware of their thinking processes so that meaningful and relevant learning processes were less achievable. The students assume that lecturers are the main source of knowledge and experts in their fields. They only obtain knowledge without knowing the process and understanding of that knowledge. It is in line with the opinion by (Tan \& Halili, 2015) which says that students are individuals who are already at the level of formal operations of the intellectual development where they are required to be able to communicate mathematical ideas into creativity. This is in line with research by (Marzuki et al., 2019) which says that communication ability can develop creative thinking skills.

Higher-order thinking skills are an important aspect of the learning process. Someone's thinking skills can affect the speed and effectiveness of learning. Therefore, the learning process should pay attention to the thinking skills to show a positive impact on the development of students' education (Heong et al., 2011) so that at the end of learning, students' creativity can be formed as a form of consistency based on the creative thinking skills.

The aspects that underlie the thought process, according to (Solso, 2008) thinking is an internal cognitive process that is formed in the mind but decision making is reflected in the 
form of behavior. In other words, thinking involves the activity of gaining knowledge or an effort to recognize something with one's own experience that is occurring in the thought which is then decided by a particular action; 2) thinking is a process that involves some manipulation of knowledge in the cognitive system. In thinking, there is a series of actions where individuals relate the information needed in making decisions; 3 ) thinking is direct and produces behaviors that solve problems or lead directly to solutions.

A person needs two mathematical thinking skills, namely creative thinking which is often identified with intuition and analytic thinking skill which is identified with logical thinking skills. Pehkonen (Fitriarosah, 2016) states that this skill is a combination of divergent thinking skills and logical thinking skills based on awareness and intuition. The creative thinking skill used in problem-solving will produce many possible answers to the same question in determining the solution. Furthermore, logical thinking will form correct conclusions according to the rules of logic and according to the previously known knowledge. Kiesswetter (Mahmudi, 2010) further explains that the flexible thinking skill is also one aspect of creative thinking skills that must be possessed in solving problems as a form of mathematical thinking skill by connecting mathematical concepts as a form of development of creative thinking processes in solving mathematical problems.

Measuring the creative thinking skill, according to (Worthington, 2006), can be done by exploring the thinking skill through mathematical work as a form of representation of the creative thinking process. The work in this case is in the form of students' creativity which includes the aspects of fluency, flexibility, novelty, and elaboration in solving mathematical problems. Meanwhile (McGregor, 2007) measures creative thinking skills by basing on what is communicated, both oral and written. It can be in the form of work-related tasks, problemsolving, or oral answers to questions. The creative thinking skill in this research is shown from the results of students' work related to divergent thinking that pays attention to the aspects of fluency, flexibility, novelty, and elaboration in solving calculus problems characterized by HOTS.

The creative thinking skill in this study was measured based on the indicators of fluency, flexibility, novelty, and detail. According to (Munandar, 2012), creative thinking skill has several aspects as follows: (1) The aspect of fluency is measured through a) skills to solve problems and provide many answers to the problems or b) providing many examples or statements about certain mathematical concepts or situations; (2) The aspect of flexibility is measured through a) the skills to use problem-solving strategies or b) providing a variety of examples of statements about certain mathematical concepts or situations; (3) The aspects of novelty which is measured through a) the skills to use new, unique, or unusual strategies to resolve problems or b) providing examples or statements that are new, unique, or unusual; (4) The aspect of detail (Elaboration) which is measured through the skill to explain certain mathematical procedures, answers, or mathematical situations in detail. The explanation should use concepts, representations, terms, or mathematical notations. The scoring guidelines used to measure the creative thinking skill can be seen in Table 1 .

Table 1. Scoring Guidelines for Students' Creative Thinking Skill

\begin{tabular}{lll}
\hline Measured aspects & Criteria for Creative Thinking Skills & Score \\
\hline
\end{tabular}




\begin{tabular}{lll}
\hline Fluency & $\begin{array}{l}\text { Providing more than two correct solutions. Using relevant } \\
\text { mathematical strategies and procedures with complete argument } \\
\text { analysis }\end{array}$ & 4 \\
$\begin{array}{l}\text { Providing more than one correct solution and mostly using relevant } \\
\text { mathematical strategies and procedures to provide more complete } \\
\text { reasons }\end{array}$ & 3 \\
$\begin{array}{l}\text { Providing one correct solution and using appropriate mathematical } \\
\text { strategies and procedures with non-detailed reasons }\end{array}$ & 2 \\
\hline $\begin{array}{l}\text { Providing one correct answer or solution and using mathematical } \\
\text { strategies and procedures accordingly, but without reason }\end{array}$ & 1 \\
\hline $\begin{array}{l}\text { Cannot provide solutions or answers } \\
\text { Flexibility }\end{array}$ & $\begin{array}{l}\text { Finding more than one way to solve the problem and entirely using } \\
\text { appropriate mathematical strategies and procedures }\end{array}$ & 0 \\
\hline $\begin{array}{l}\text { Finding more than one way to solve a problem and mostly using } \\
\text { appropriate mathematical strategies and procedures }\end{array}$ & 3 \\
\hline $\begin{array}{l}\text { Finding one way to solve a problem and using appropriate } \\
\text { mathematical strategies and procedures without complete reasons }\end{array}$ & 2 \\
\hline $\begin{array}{l}\text { Finding one way to solve the problem and using appropriate } \\
\text { mathematical strategies and procedures without reasons }\end{array}$ & 1 \\
\hline $\begin{array}{l}\text { Cannot provide solutions or answers } \\
\text { Describing the solution of the problem in a different way from others } \\
\text { that is relevant to the concept intended completely and appropriately }\end{array}$ & 4 \\
\hline $\begin{array}{l}\text { Describing the solution of the problem in a different way from others } \\
\text { that is relevant to the concept although incomplete and inaccurate } \\
\text { with the appropriate mathematical procedures }\end{array}$ & 3 \\
\hline $\begin{array}{l}\text { Describing the solution of the problem differently from others but } \\
\text { does not correspond to the concept and incomplete }\end{array}$ & 2 \\
\hline $\begin{array}{l}\text { Describing the completion of the given problem in a different way } \\
\text { than others without reason }\end{array}$ & 1 \\
\hline can provide a solution or answer & 3 \\
\hline $\begin{array}{l}\text { Describing the solution of a problem in detail correctly } \\
\text { Describing the solution of a problem in detail although the analysis } \\
\text { Descriments is not complete }\end{array}$ & 3 \\
\hline $\begin{array}{l}\text { Describing unspecific solution to a problem } \\
\text { Cannot provide solutions or answers }\end{array}$ & 2 \\
\hline
\end{tabular}

The creative thinking skill in solving problems is constructed by different level, according to (Tatag Yuli Eko Siswono, 2011) the level of creative thinking is in line with the work produced by students. The levels of creative thinking skills in this study are:

Table 2. The Level of Students' Mathematical Creative Thinking Skill

\begin{tabular}{ll}
$\begin{array}{c}\text { Creative Thinking Skill } \\
\text { Levels }\end{array}$ & \multicolumn{1}{c}{ Indicators } \\
\hline Level 4 (Very Creative) & $\begin{array}{l}\text { Students can show fluency, flexibility, novelty, and detail in solving } \\
\text { problems }\end{array}$ \\
\hline Level 3 (Creative) & Students can show fluency, flexibility, and novelty in solving problems \\
\hline Level 2 (Fairly Creative) & Students can show fluency, flexibility, and/or novelty in solving problems \\
\hline Level 1 (Less Creative) & Students are only able to show fluency in solving problems \\
\hline Level 0 (Not Creative) & $\begin{array}{l}\text { Students are unable to show fluency, flexibility, novelty, and detail in } \\
\text { solving problems }\end{array}$ \\
\hline
\end{tabular}


To measure the level of creative thinking skill, the researchers modified the guidelines proposed by (T. Y. E. Siswono, 2008) as follows:

Table 3. The Level Students Creative Thinking Skill

\begin{tabular}{cc}
\hline Score & The Level of Creative Thinking Skill \\
\hline $40 \leq \mathrm{S}<50$ & Level 4 (Very Creative) \\
\hline $30 \leq \mathrm{S}<40$ & Level 3 (Creative) \\
\hline $20 \leq \mathrm{S}<30$ & Level 2 (Fairly Creative) \\
\hline $10 \leq \mathrm{S}<20$ & Level 1 ( Less Creative) \\
\hline $0 \leq \mathrm{S}<10$ & Level 0 (Uncreative) \\
\hline
\end{tabular}

\section{METHODS}

The method employed in this research was a descriptive-qualitative method to describe the object of research based on the data of students' creative thinking skills in solving higher-order thinking skill (HOTS) questions. This research was conducted on the students of Mathematics Education Study Program at the Tarbiyah and Teacher Training Faculty of IAIN Langsa. The subjects were 28 third semester students. The subjects were selected using non-probability sampling technique, specifically the purposive sampling and snowball sampling. The researchers determined a particular informant following the objectives and the needs of the research. The selection of the subjects was based on the consideration that the samples taken were emphasized on the quality of their understanding and the high mathematical skill in the calculus course. The data collecting techniques used were tests and interviews. There were 4 description questions characterized by HOTS based on indicators of creative thinking skill. The interviews were focused on the questions that have been given in the tests. Before the tests were given, they were validated for their validity, reliability, level of difficulty, and discriminating index. Then, the data were reduced using triangulation techniques which were the combination of tests, interviews, and field notes.

\section{RESULTS AND DISCUSSION}

The results of the tests were analyzed descriptively based on the indicators of creative thinking skills. The results of students' creative thinking tests obtained an average score of 38.43 with the overall level of creative thinking skills classified as creative. The number of students based on their level of creative thinking skill can be seen in the following table:

Table 4. The Percentage of Creative Thinking Skill Levels

\begin{tabular}{ccc}
\hline Creative Thinking Skill Levels & Number of Students & Percentage \\
\hline Very Creative & 10 & $35.71 \%$ \\
\hline Creative & 14 & $50 \%$ \\
\hline Fairly Creative & 4 & $14.29 \%$ \\
\hline
\end{tabular}

The students' answers based on the indicators creative-thinking skill level are described in the following discussion: 


\section{The Subject DRQ with Very Creative level thinking skill}

Based on the results of interviews with DRQ, he stated that he understood the problems so that he can easily solve all four problems. In the fluency indicator, DRQ provided more than one solution to the problem. He provided three solutions to answer the following questions:

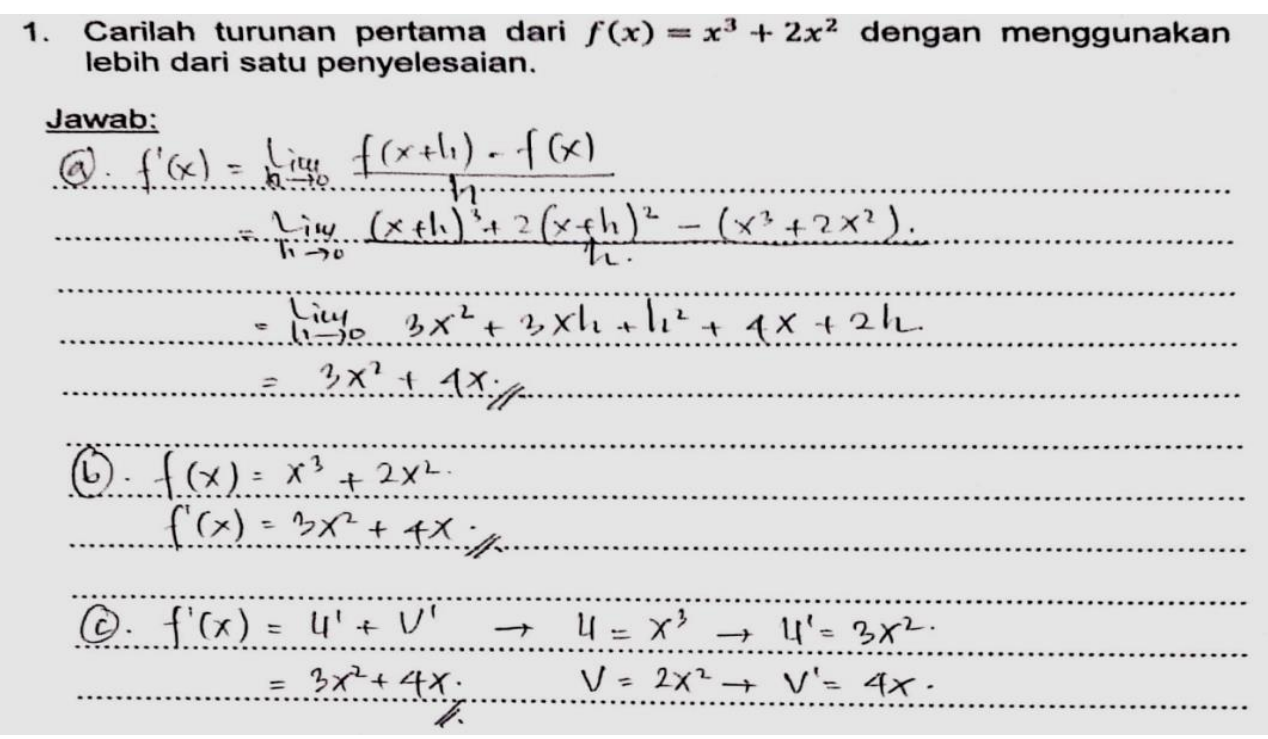

DRQ's Answers on the Fluency Indicators

In the flexibility indicator, DRQ used 3 kinds of solution strategies accompanied by reasons. It can be seen in the following answers:

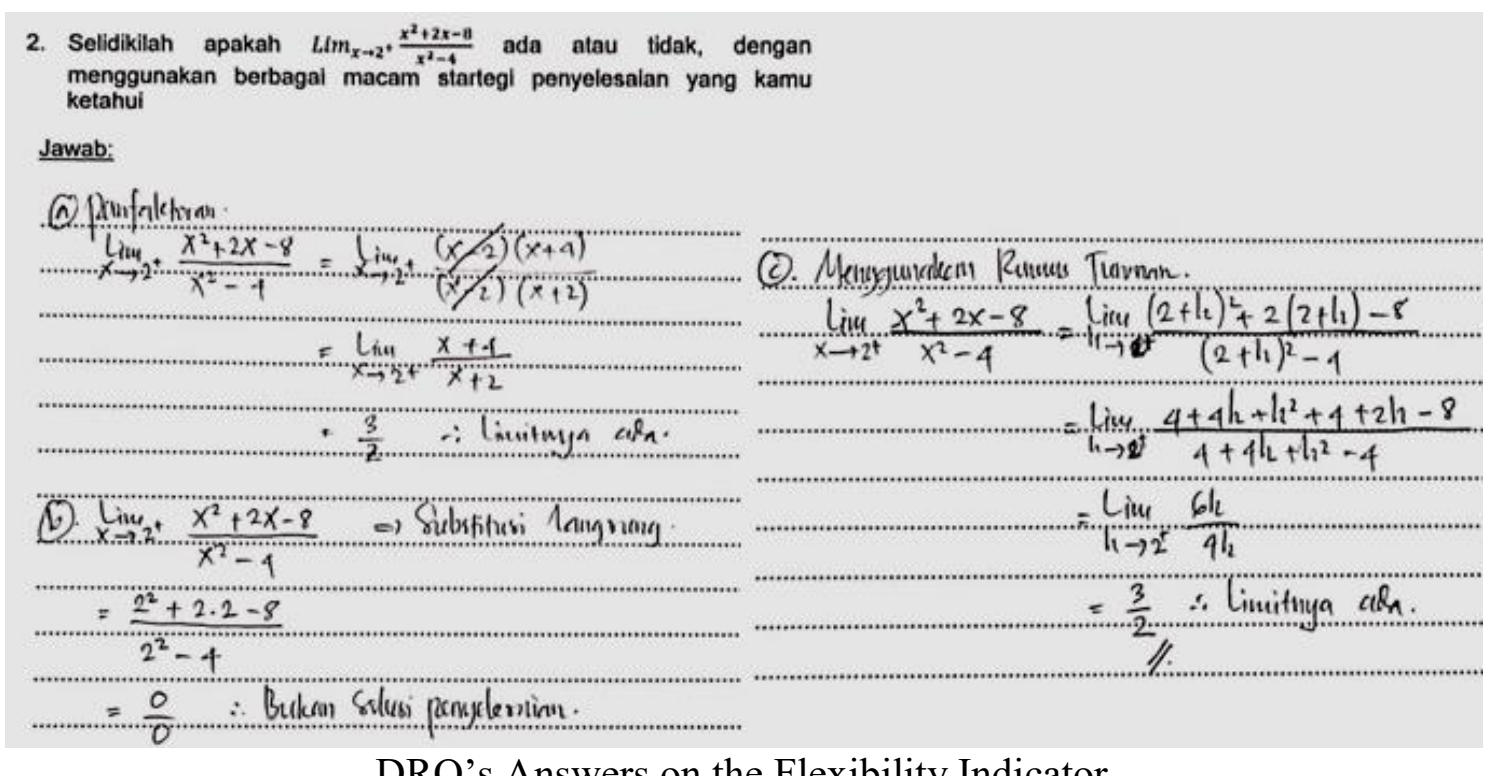

In question 3 of the novelty indicator, DRQ solved the problem in a new way according to the concepts that had been learned. The following are DRQ's answers to problem 3. 


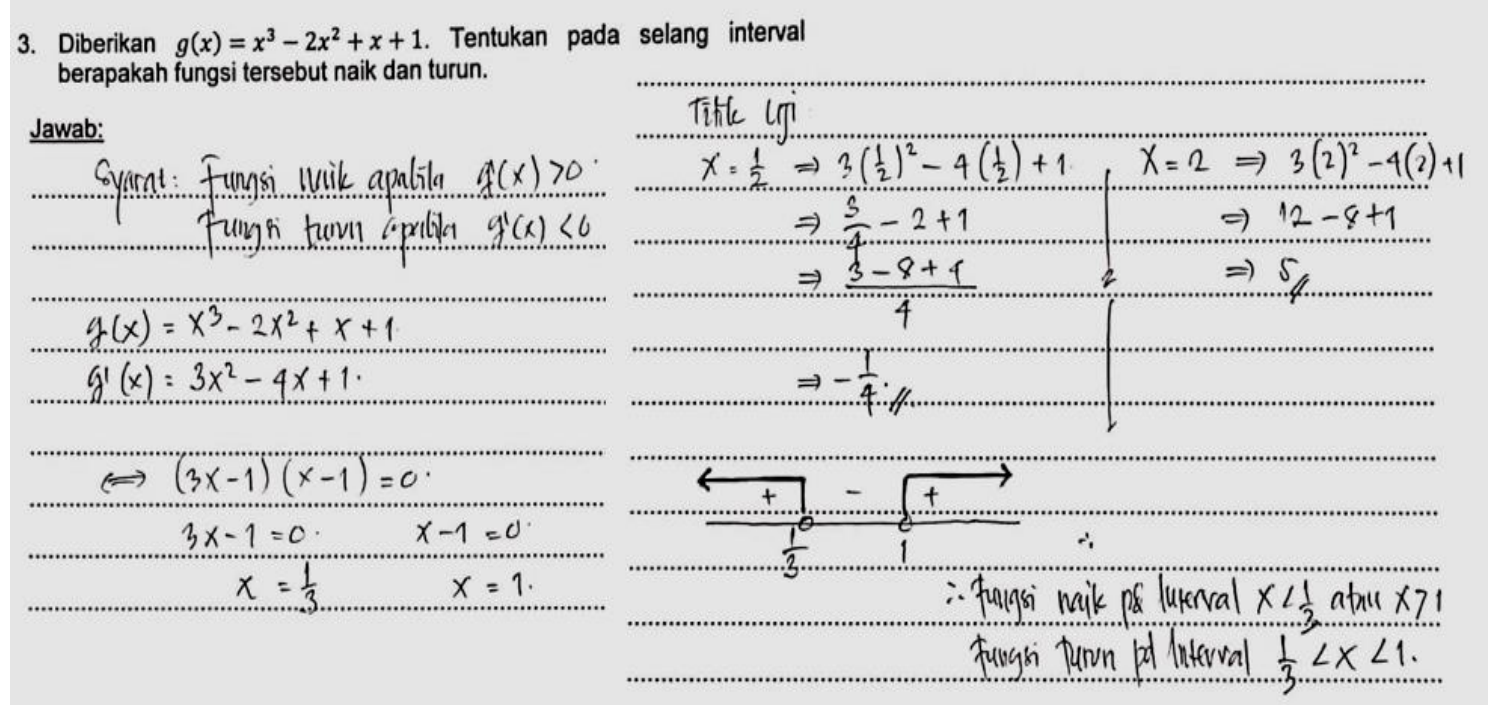

DRQ's Answers on the Novelty Indicator

In the detailed indicator (Problem 4), DRQ provided answers in detail, coherently, and in an orderly manner according to the procedures. It can be seen in the following answers:

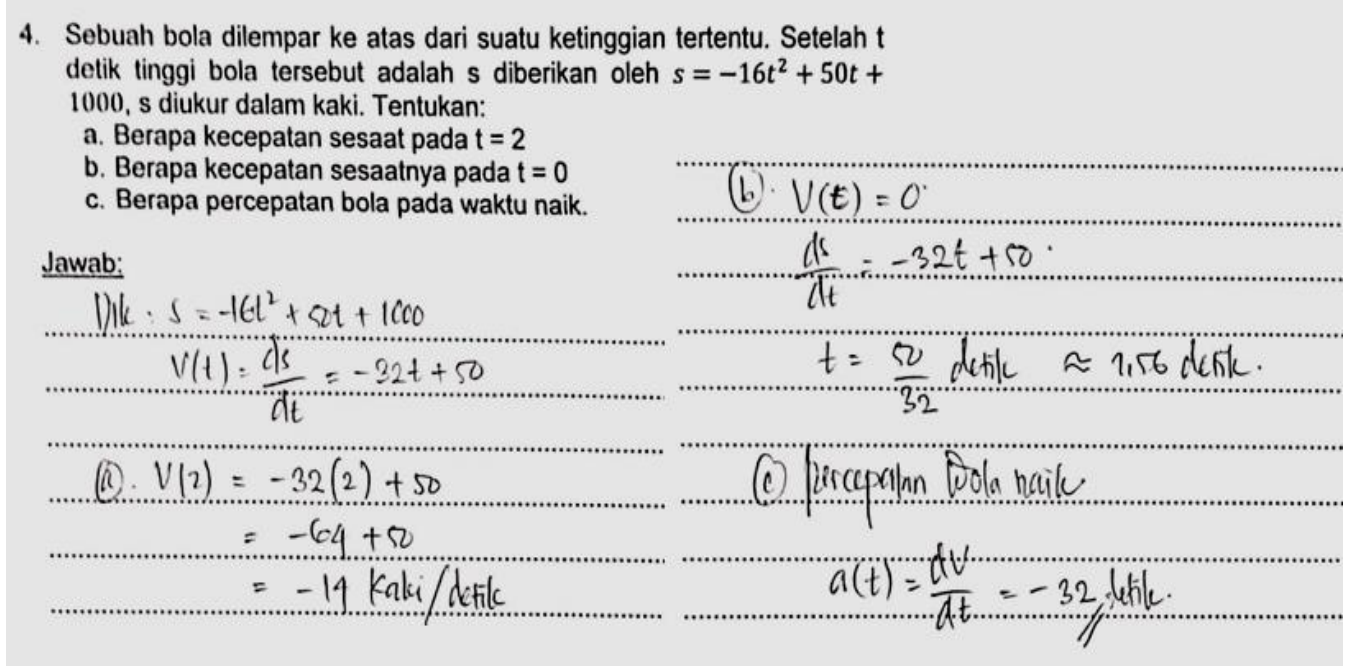

\section{DRQ Answers on the Detail Indicators}

\section{Subject SCA with Creative Level Thinking Skill}

Based on the results of interviews with SCA, he stated that he understood the problems but he forgot the formula.

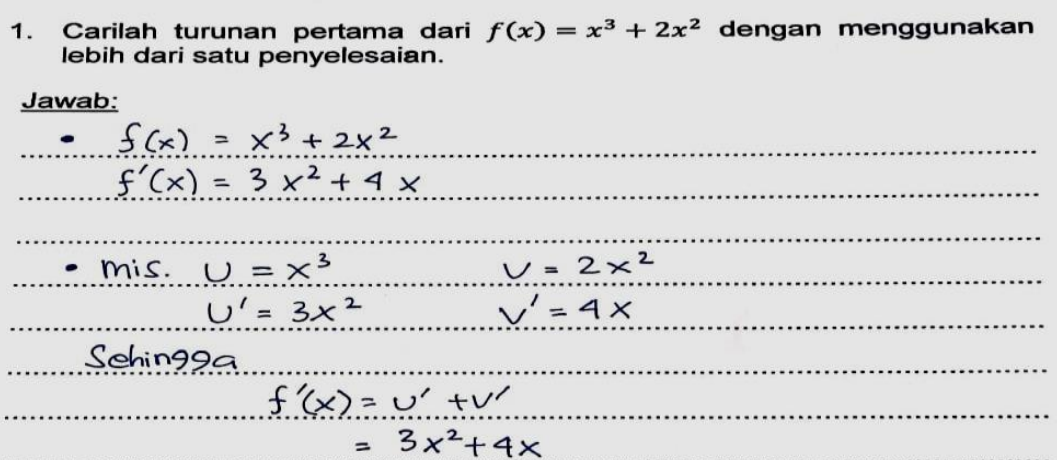

SCA's Answer on the Fluency Indicator 
In the flexibility indicator (Problem 2), SCA used 2 different types of solution strategies. However, in the second strategy, he could not find a solution to the problem. SCA could not mention whether there was a limit to the problem. The following is the SCA's answer to the second problem:

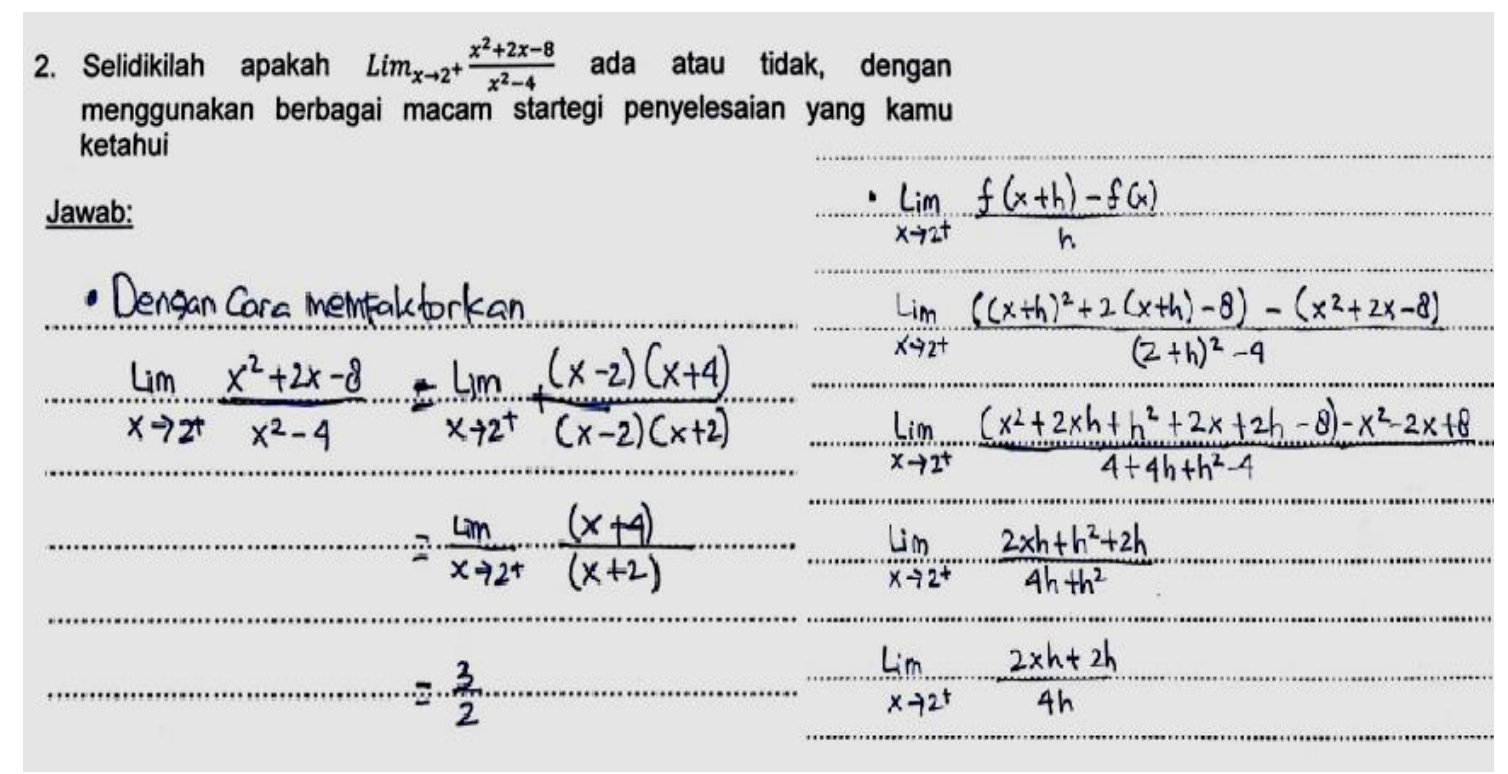

SCA's Answer on the Flexibility Indicator

Based on the results of the interview, SCA could solve the problem by himself according to his level of understanding. However, he could not describe the interval and test points because he forgot. The following is SCA's answer to the third question:

3. Diberikan $g(x)=x^{3}-2 x^{2}+x+1$. Tentukan pada selang interval berapakah fungsi tersebut naik dan turun.

Jawab:

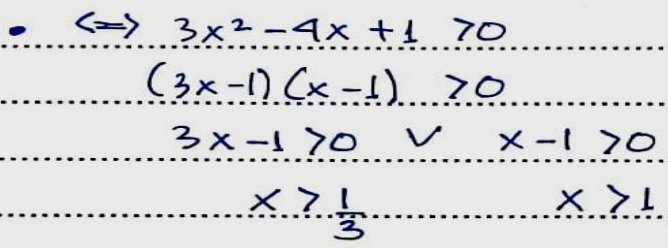

- $g^{\prime}(x)>0$ pada lnterval $x<\frac{1}{3}$ dan $x \geq 1$

- $g^{\prime}(x)<0$ pada lnterval $\frac{1}{3} \leqslant x \leqslant 1$

SCA's Answer on the Novelty Indicator

The results of the interview with SCA on detail indicator (Problem 4) showed that he could provide solutions to the problem in detail, coherently, and in an orderly manner based on the procedure. 


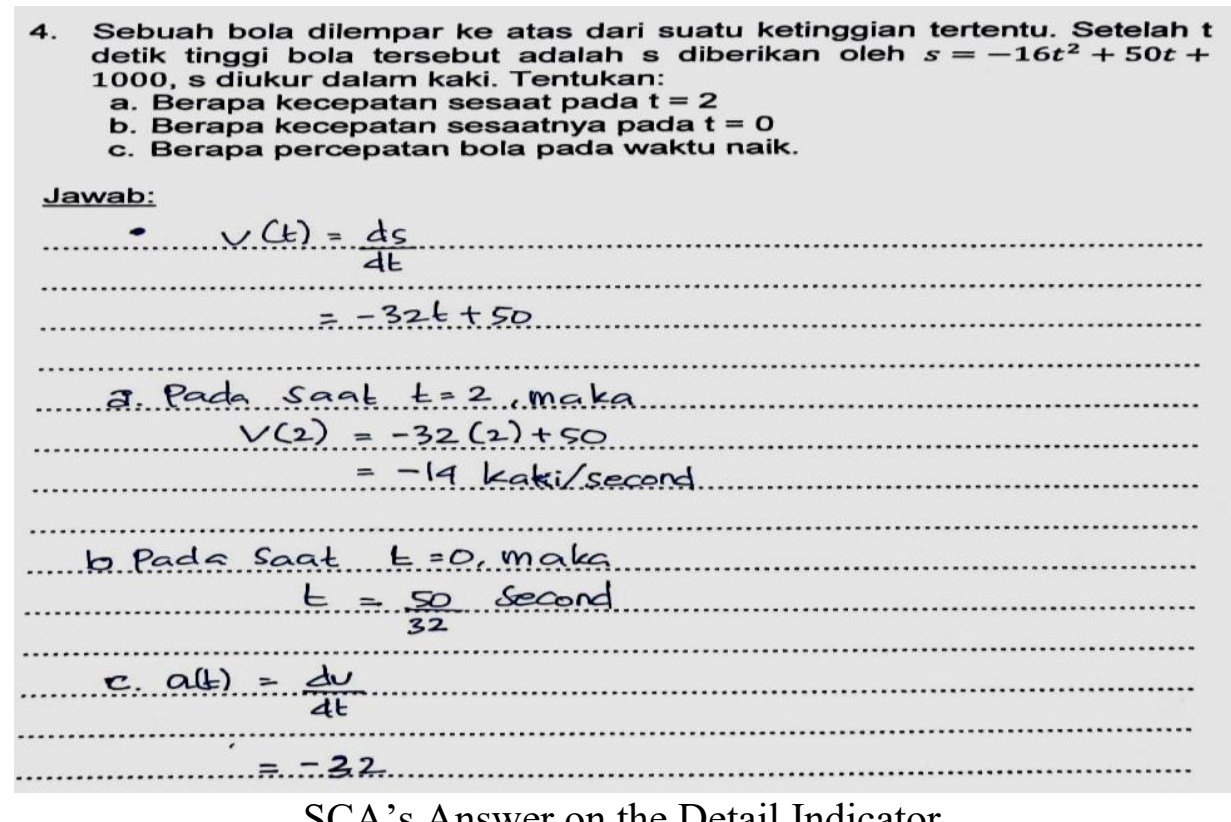

\section{CONCLUSIONS}

The results of the analysis of students' creative thinking showed that the average score obtained was 38.43 with the overall level of thinking skills at the creative level. Only 10 students $(35.71 \%)$ were included in the highly creative level and met the four indicators of creative thinking skill. 14 students (50\%) were included on the creative level and met the indicators of creative thinking skills. 4 students $(14,29 \%)$ were included in the fairly creative level since they were only able to achieve the fluency and flexibility indicators. As a whole, it can be concluded that the creative thinking skill of Mathematics Education study program students was in the creative category with $30 \leq \mathrm{S}<40$ range of grades.

It is recommended for further researchers to use a particular learning model or approach to see its correlation with higher-order thinking skills, especially in the calculus subject. This research needs to develop an assessment format for HOTS, both in terms of thinking skills or gender characteristics.

\section{AUTHOR CONTRIBUTIONS STATEMENT}

$\mathrm{MZ}$ and IR both conducted research. They put all the instruments together and put this article together.

\section{REFERENCES}

Fitriarosah, N. (2016). Prosiding Seminar Nasional Pendidikan Matematika 2016 Universitas Kanjuruhan Malang. Pengembangan instrumen berfikir kreatif matematis untuk siswa SMP , 1(1997), 243-250.

Heong, Y. M., Othman, W. B., Yunos, J. B. M., Kiong, T. T., Hassan, R. Bin, \& Mohamad, M. M. B. (2011). The level of marzano higher order thinking skillsamong technical education students. International Journal of Social Science and Humanity, 1(2), 121-125. 
Kusuma, M. D., Rosidin, U., Abdurrahman, A., \& Suyatna, A. (2017). The development of higher order thinking skill (HOTS) instrument assessment in physics study. IOSR Journal of Research \& Method in Education (IOSRJRME), 07(01), 26-32.

Mahmudi, A. (2010). Mengukur kemampuan berpikir kreatif matematis, makalah dipersentasikan. Seminar Nasional Matematika XV.

Marzuki, Asih, E. C. M., \& Wahyudin. (2019). Creative thinking ability based on learning styles reviewed from mathematical communication skills. Journal of Physics: Conference Series, 1315(1), 0-7.

McGregor, D. (2007). Developing thinking; developing learning : A guide to thinking skills in education.

Munandar, U. (2012). Pengembangan kreativitas anak berbakat. Rineka Cipta.

Schleicher, A. (2018). PISA 2018 insights and interpretations. 64.

Siregar, I. (2012). Menerapkan pendekatan model-eliciting activities untuk meningkatkan kemampuan berpikir kreatif matematis siswa SMP. Jurnal Pendidikan Matematika Sigma Didaktika UPI Bandung. 1 (1), I(1).

Siswono, T. Y. E. (2008). Proses berpikir kreatif siswa dalam memecahkan dan mengajukan masalah matematika. Jurnal Ilmu Pendidikan, 15(1), 1-14.

Siswono, Tatag Yuli Eko. (2011). Level of student's creative thinking in classroom mathematics. Educational Research and Reviews, 6(7), 548-553.

Solso, R. L. (2008). Psikologi kognitif. Erlangga.

Tan, S. Y., \& Halili, S. H. (2015). Effective teaching of higher-order thinking (HOT) in education. The Online Journal of Distance Education and E-Learning, 3(2), 41-47.

TIMSS. (2015). Timss 2015 International Results in Science Saved. Distribution of science achievement. http://timss2015.org/timss-2015/science/student-achievement/distributionof-science-achievement/

Worthington, M. (2006). Creativity meets Mathmatics. Practical Pre-School, 3, 1-8. 